Article

\title{
Appropriating Moral Sense: A Rereading of Kant's Ethics ${ }^{1}$
}

\section{Dennis A. De Vera}

\begin{abstract}
My main concern in this paper is to develop some ideas within the Kantian ethical tradition. More precisely, my aim is to develop an ethical perspective that is grounded upon the Kantian ideas of autonomy and ideal of the person (Kant's notion of humanity) as fundamental starting points for a coherent account of Kant's ethics in contrast to the deontological duty-based interpretation of his moral philosophy, then sketch, subsequently, some suggestions to show why this reading has more philosophical import than what a deontological reading may provide. I take no issue for the time being, however, as to whether or not the perspective I have in mind leads to either a Kantian orthodoxy or a revisionist direction in Kant scholarships.
\end{abstract}

Keywords: Kant, Rawls, moral obligation, practical reason

\section{Introduction}

I $\mathrm{n}$ the preface to Barbara Herman's The Practice of Moral Judgment, Herman assails what we have come to know as a purely deontological reading of Kant's Ethics. She notes that while a deontological reading of Kant's ethics does have a connection to what the latter says, she nonetheless comments that this way of framing Kant is in some respects inadequate, because of the weight it attaches to the idea of duty rather than the good. ${ }^{2}$ Since said reading puts too much emphasis on the role of duty and takes it as the central defining

${ }^{1}$ This paper is a revised version of the draft of my supposedly MA thesis in Philosophy at the University of the Philippines-Diliman. It started as a graduate seminar paper I submitted for my Philo 271 class under Dr. Zosimo E. Lee. I owe so much of what I understand about Immanuel Kant and John Rawls from him. I am thankful as well to the anonymous referees for their charitable reading and generous comments about the paper.

2 See Barbara Herman, Preface to The Practice of Moral Judgment (Cambridge, MA: Harvard University Press, 1999), vii.

(c) 2019 Dennis A. De Vera

https://www.kritike.org/journal/issue 25/de vera december2019.pdf

ISSN 1908-7330 


\section{A REREADING OF KANT'S ETHICS}

characteristic of Kant's moral philosophy, it becomes oblivious to other concepts that are in fact similarly important to the latter's moral writings.

My main concern then in this paper is to develop some ideas within the Kantian ethical tradition. More precisely, my aim is to develop an ethical perspective that is grounded upon the Kantian ideas of autonomy and ideal of the person (Kant's notion of humanity) as fundamental starting points for a coherent account of Kant's ethics in contrast to the deontological duty-based interpretation of his moral philosophy, then sketch, subsequently, some suggestions to show why this reading has more philosophical import than what a deontological reading may provide. I take no issue for the time being, however, as to whether or not the perspective I have in mind leads to either a Kantian orthodoxy or a revisionist direction in Kant scholarships.

My argument nonetheless is not meant to be conclusive, but rather suggestive, for doing the former requires a very rich philosophical acumen and a significant number of thorough readings of Kant's works in moral philosophy. This coheres, I think, with Arnulf Zweig's caveat that Kant's moral writings remain an "inexhaustible subject for scholarly debate and analysis" owing to its wider range and complexity, notwithstanding its seeming connections to his entire critical philosophy. ${ }^{3}$ Nevertheless, I hold firm to the idea that there is much more to be said about Kant's moral philosophy than one finds in any deontological reading of Kant's ethical theory.

The perspective I develop, if I may suggest, is nonetheless situated within the fundamental question: To whom do we owe our obligation to be moral? Or put in another way: To whom do we owe our moral sense? The underlying hypothesis here is based on the idea that since the ultimate concern of Kant's moral philosophy is to establish the supreme principle of morality, it logically follows that whatever underlies this supreme principle of morality must be the basis for reading Kant's ethics.

Thus, in responding to this question I take the view that the underlying principle of Kant's moral philosophy and thus the fundamental starting point for a possible interpretation of his ethics rests on two essential concepts: those of autonomy and the Kantian ideal of the person. More specifically, I take the view that the basis of our moral sense or the root of our obligation to be moral is grounded upon these concepts. Briefly stated, what underlies Kant's pursuit of the supreme principle of morality is a moral sense that is essentially characterized by both autonomy and the ideal of the person.

In putting forward the concepts of autonomy and the ideal of the person as fundamental bases of our moral sense or our obligation to be moral, the

3 See Arnulf Zweig, "Reflections on Kant's Ethics" in The Blackwell Guide to Kant's Ethics, ed. by Thomas E. Hill, Jr. (United Kingdom: Blackwell Publishing Ltd., 2009), 257.

(c) 2019 Dennis A. De Vera

https://www.kritike.org/journal/issue 25/de vera december2019.pdf

ISSN 1908-7330

(cc) BY-NC-ND 
perspective I develop seeks to lay down a much broader moral landscape within which Kant's moral philosophy may be properly situated and understood. Two considerations are worth noting here, though. The first consideration is anchored on the condition that the realization of the moral law is the articulation of autonomy itself. It is through autonomy or autonomous moral deliberation that an individual realizes the need to act from the motive of duty. Whereas, the second consideration is propelled by the belief that this capacity for autonomy or autonomous moral deliberation is only meaningfully possible if taken within the context of Kant's ideal of the person (Kant's humanity), whose primary motivation rests upon the goal of restoring the purity of the moral law through the moral cultivation of the natural predisposition to personality, the main aim of which is to realize Kant's kingdom of ends.

Throughout, I think of our moral sense, in so far as it is characterized by both autonomy and the ideal of the person, as our fundamental capacity to discern whether or not a given act is morally worthy or morally right. ${ }^{4} \mathrm{We}$ appeal to our moral sense when there exists, for example, conditions that offend our sense of morality or our deeply held beliefs about the morally good life-say, inhumane treatment of laborers, deliberate infliction of pain and suffering, or even unjust killings of persons. Our moral sense, in this respect, operates within those conditions. The Kantian perspective I have in mind is set out to show how our moral sense arises from the directives that we give to ourselves when faced for instance with the like conditions. Similarly, it seeks to illustrate, why our capacity for a moral sense is the fundamental basis for a satisfactory account of Kantian morality on one hand and of moral responsibility on the other hand.

My discussions nevertheless are motivated largely by John Rawls's appropriation of Kant's ethics. ${ }^{5}$ Rawls's appropriation of the latter's ethics, as

${ }^{4}$ I take "moral sense" here in the same way I understand how we are able to judge the moral worthiness of an act through a prior determination of the moral law by our practical reason. Thus, I take Kant's meaning of "moral sense" somewhat loosely, as a capacity for moral perception. For an account of Kant's moral sense, see Immanuel Kant, The Metaphysics of Morals in Practical Philosophy, trans. and ed. by Mary J. Gregor (Cambridge: Cambridge University Press, 1996) 6:400. This is in contrast to the notion of 'moral sense' found among moral sense theories in the tradition of Francis Hutcheson, David Hume, and Adam Smith, whose key idea is premised on the assumption that our moral approbation or moral disapprobation is determined by 'passion' or 'sentiment' without the prior determination of reason. See for example the following works for this supposed difference: Francis Hutcheson, An Inquiry into the Original of our Ideas of Beauty and Virtue in Two Treatises (Indianapolis: Liberty Fund, 2004); Alasdair MacIntyre, Hume's Ethical Writings: Selections from David Hume (Notre Dame: University of Notre Dame Press, 1965); and Adam Smith, The Theory of Moral Sentiments (Cambridge: Cambridge University Press, 2004).

${ }^{5}$ See John Rawls, Lectures on the History of Moral Philosophy (Cambridge, MA: Harvard University Press, 2000), 143-325. 


\section{A REREADING OF KANT'S ETHICS}

I take it, lays down a much broader moral landscape for any decent reading of Kant's moral philosophy. Guided by this belief, the Kantian perspective I suggest here though is not meant as a comprehensive reading of Kant's ethics. Instead, I take it as a kind of moral reflection or an example of ethical theorizing on the most fundamental principles embedded in Kant's moral writings and how these principles may be framed to fit together a more coherent understanding of Kant's moral philosophy.

Granting, then, the context I have sketched, the Kantian perspective I intend to develop runs as follows. My main concern is to outline the features of an ethical theorizing on Kant's ethics of autonomy that is derived from Kant's account of moral psychology, namely, the concepts of autonomy and the ideal of the person, specifically, his account of the natural predisposition to personality. As a form of ethical theorizing, these concepts, combined with other Kantian concepts, are synthesized in such a way that they serve as grounds that underlie Kant's search for the supreme principle of morality. That, while it recognizes the importance of duty, akin to a deontological reading of Kant, it takes autonomy and the ideal of the person as prior concepts that stand at the base of understanding Kant's ethics.

More precisely, in the first section, I sketch an outline of the analytic to a Kantian ethics of autonomy, bearing in mind the necessary features, fundamental assumptions and reasons pertinent to a rereading of Kant's ethics. Then, in the second section, I lay down two considerations that may show, hopefully, how the concepts of autonomy and the ideal of the person, may be developed in order to account for moral sense. In doing so, it indirectly suggests why the idea of moral worthiness is much more central to Kant's ethics. In the final section, I outline two suggestions, through a close reading of some of Kant's important works in moral philosophy, to show why the notion of moral sense is to be taken as central to a rereading of Kant's ethics.

\section{Analytic to a Kantian Ethics of Autonomy}

Before I set out the reading, however, let me situate the analytic of the question "To whom do we owe our obligation to be moral?" within the narrower context of ethical theorizing. ${ }^{6}$ I think a greater part of the problem in responding to this question is the identification of the relevant concepts that may be associated with moral sense, notwithstanding the issue as to how these concepts must be situated, let alone arranged. These concepts, in a

${ }^{6}$ The style and manner of writing section II is an influence of John Rawls. Rawls's presentation has given me the needed direction to situate the question within the narrower context of ethical theorizing. For an account of Rawls's presentation, see John Rawls, "The Sense of Justice" in Collected Papers, ed. by Samuel Freeman (Cambridge, MA: Harvard University Press, 1999), 97-98.

(C) 2019 Dennis A. De Vera

https://www.kritike.org/journal/issue 25/de vera december2019.pdf

ISSN 1908-7330

(c) $\mathrm{BY}-\mathrm{NC}-\mathrm{ND}$ 
fundamental way, must be able to provide a satisfactory basis for an account of the moral sense itself as well as a justifiable ground that may explain moral responsibility. I take this to mean that said concepts are recognized and acknowledged as such concepts that (a) inhere in a person (being a bearer of moral sense), (b) provide sufficient authority that defines the terms of any moral deliberation (sort of a defining condition), and (c) offer grounds that support an account of moral responsibility itself. By this, I mean that these concepts are characteristics of the bearer of moral sense and basis of moral responsibility, that is, they are such concepts that give rise to and recognition of moral obligation, if not respect for the moral law. In this regard, these concepts are viewed as conditio sine qua non of moral practice. This is to say that when faced with a moral dilemma or any concern that demands moral assessment, these concepts are capable of imposing constraints, if not reasonable terms, to moral deliberation on one hand or to moral judgment on the other hand. This is to say further that given any difficulty in arriving at such moral judgment, these concepts provide the necessary moral background for discerning why a given act is morally worthy or why a given moral law is worth respecting or worth doing. Thus, questions of the moral worthiness of an act or the appropriateness of the moral judgement arise only when these concepts are acknowledged as fundamental to and intrinsic in the constitution of the bearer of moral sense. The acknowledgment that is given, in turn, illustrates how its role as a moral requisite is made to be essentially prior to any recognition of moral obligation or acknowledgement of duty. Its role, in this sense, defines the concepts' respective fits in the development of a satisfactory account of moral obligation and of moral responsibility.

That said, the concepts that may be associated with moral sense, when moral sense is applied to human actions or when moral sense is appealed to, given a moral dilemma, are as follows: (a) the concept of practical reason and (b) the concept of freedom or autonomy. The idea of practical reason here is understood as that which determines human actions ${ }^{7}$ or the capacity, under the direction of reason, to discern what actions are morally worthy or otherwise. ${ }^{8}$ Whereas, the idea of freedom or autonomy, is understood as reason's "ability to be of itself practical," that is, what Kant himself refers to as "positive freedom," ${ }^{9}$ or the capacity to act in conformity with its own laws (Wille) and not from the determinations of impulses or

7 See Christine M. Korsgaard, Creating the Kingdom of Ends (Cambridge: Cambridge University Press, 1999), 111.

8 See Immanuel Kant, Religion within the Boundaries of Mere Reason, in Religion and Rational Theology, trans. and ed. by Allen Wood and George Di Giovanni (Cambridge: Cambridge University Press, 1996), 6:28.

${ }^{9}$ Kant, Metaphysics of Morals, 6:214. 


\section{A REREADING OF KANT'S ETHICS}

inclinations made by choice (Willkür)..$^{10}$ Autonomy or freedom, in this sense, is taken to mean as serving as the supreme principle of morality. ${ }^{11}$ While Kant is explicit that we cannot prove that there is freedom, he nevertheless admits that "we can only act under the idea of freedom." 12 Similarly, although he acknowledges that freedom is a mere idea, "to act in conformity with this idea is to be free in the practical sense."13 These concepts, consequently, form the core ideas of Kant's ethics of autonomy.

One may ask, in what sense are these concepts crucial to Kant's ethics of autonomy? One way of responding to this question is to try to situate it within the larger context of Kant's concept of the ideal of the person. Although said ideal finds its clearest formulation in John Rawls's appropriation of Kant's ethics, as we shall see in later sections, its initial undertakings are laid out as early as Kant's works on anthropology and education. Allen Wood however remarks that even with these beginnings, Kant has to contend with the poverty of anthropology in his time. Wood gives two reasons why this is the case. On the one hand, there is an inherent difficulty to discuss the question primarily because of our limited capacities to "acquire knowledge of human nature."14 This is Kant's primary reason for being reluctant to discuss the problem itself. ${ }^{15}$ On the other hand, there are

10 Kant, Metaphysics of Morals, 6:213. See also Immanuel Kant, Groundwork of the Metaphysics of Morals, in Practical Philosophy, trans. and ed. by Mary J. Gregor and Allen Wood (Cambridge: Cambridge University Press, 1996), 4:443.

${ }^{11}$ See Immanuel Kant, Critique of Practical Reason, in Practical Philosophy, trans. and ed. by Mary J. Gregor and Allen Wood (Cambridge: Cambridge University Press, 1996), 5:33. See also Helmut Holzhey and Vilem Mudroch, Historical Dictionary of Kant and Kantianism (Landham, Maryland: The Scarecrow Press, Inc., 2005), 59.

12 See Immanuel Kant, "Notes on Moral Philosophy," in Notes and Fragments, ed. by Paul Guyer and trans. by Curtis Bowman, Paul Guyer, and Frederick Rauscher (Cambridge: Cambridge University Press, 2005), 15:458.

${ }^{13}$ Kant adds: "Freedom is thus practically necessary-thus a human being must act according to an idea of freedom, and he cannot otherwise." See Immanuel Kant, Lectures on Metaphysics, trans. and ed. by Karl Ameriks and Steve Naragon (Cambridge: Cambridge University Press, 1997), 29:898.

14 See Allen Wood, "Kant and the Problem of Human Nature," in Essays in Kant's Anthropology, ed. by Brian Jacobs and Patrick Kain (Cambridge: Cambridge University Press, 2003), 39.

${ }^{15}$ See, for example, Immanuel Kant, "Universal Natural History and Theory of the Heavens or, Essay on the Constitution and the Mechanical Origin of the Whole Universe according to Newtonian Principles," trans. by Olaf Reinhardt, in Natural Science, ed. by Eric Watkins (Cambridge: Cambridge University Press, 2012), 1:366. I have touched upon this while reading Allen Wood's Kant's Ethical Thought (Cambridge: Cambridge University Press, 1999). Kant expresses this worry as follows: "We are not even properly familiar with what a human being actually is, even though consciousness and our senses should inform us about it; how much less will we be able to imagine what he will become in the future! Nonetheless the human soul's desire for knowledge grasps greedily for this object so distant from it and strives to shed some light in such obscure cognition." Emphasis added.

(C) 2019 Dennis A. De Vera

https://www.kritike.org/journal/issue 25/de vera december2019.pdf

ISSN 1908-7330

(cc) BY-NC-ND 
limited possibilities owing to the "poor state of anthropology at present."16 Part of the reason here perhaps is the apparent prevalence of physiological approach in understanding human nature-inquiries that link bodily organs to thought. ${ }^{17}$ In a letter to Marcus Herz toward the end of 1773 for instance, Kant repudiates this idea [physiological approach] and seeks instead a study of human nature from a pragmatic point of view - a preliminary study that "disclose[s] the sources of all the [practical] sciences, the science of morality, of skill, of human intercourse, of the way to educate and govern human beings, and thus of everything that pertains to the practical" - that can be called "knowledge of the world." 18

At the risk of appearing simplistic, let alone reductionist, one may say that Kant's repudiation of the physiological approach in understanding human nature is fueled by his deep-seated conviction on freedom and agency. ${ }^{19}$ Whereas Kant is categorical that human nature may be possibly understood from a pragmatic point of view, the extent to which "this" may be given points only to the empirical part of understanding human nature. ${ }^{20}$ The rational part, in Kant's view, is reserved to that science which is properly called morals. ${ }^{21}$ He however issues a caveat that it [moral anthropology] must not precede "the metaphysics of morals or be mixed with it." 22 Kant aptly explains why this is so:

[...] for one would then run the risk of bringing forth false or at least indulgent moral laws, which would misrepresent as unattainable what has only not been attained just because the law has not been seen and presented in its purity (in which its strength consists) or because spurious or impure incentives were used for what is itself in conformity

${ }^{16}$ Wood, "Kant and the Problem of Human Nature," 39.

17 Ibid., 40.

18 See Immanuel Kant, “To Marcus Herz, late 1773," in Correspondence, trans. and ed. by Arnulf Zweig (Cambridge: Cambridge University Press, 1999), 10:146. Although the idea of "pragmatic" here means a number of things. For the nuances in meaning see Wood, "Kant and the Problem of Human Nature," 40-42. See also Holly Wilson, Kant's Pragmatic Anthropology: Its Origin, Meaning and Critical Significance (Albany: State University of New York Press, 2006), 28 35.

${ }^{19}$ Kant's idea for instance of the autonomy of the will as a key faculty to determine an act is an instance of this agency. See Kant, Groundwork, 4:446-448. Christine Korsgaard briefly explains Kant's "agency" in the introduction of her book. See Christine Korsgaard, The Constitution of Agency: Essays on Practical Reason and Moral Psychology (Oxford: Oxford University Press, 2008), 10-13. Henry Allison similarly has an interesting discussion on agency. See Henry Allison, Essays on Kant (Oxford: Oxford University Press, 2012), 137-161, especially essay nine.

${ }^{20}$ Kant, Groundwork, 4:388.

${ }^{21}$ Kant, Groundwork, 4:388

${ }^{22}$ Kant, Metaphysics of Morals, 6:217. 


\section{A REREADING OF KANT'S ETHICS}

with duty and good. This would leave no certain moral principles, either to guide judgment or to discipline the mind in observance of duty, the precepts of which must be given a priori by pure reason alone. ${ }^{23}$

Kant's underlying reason for issuing this caveat stems, in an essential sense, from the idea that since a proper study of morals is concerned with the a priori laws of freedom and, hence, metaphysics of morals, such laws cannot be empirically conditioned or cannot be derived from empirical principles. Otherwise, said laws themselves lose their moral grip and yield instead only conditional necessity..$^{24}$ It is precisely for this reason that moral anthropology is viewed as distinct from the metaphysics of morals. In the Lectures on Ethics Kant writes:

[...] the second part [of practical philosophy] is philosophia moralis applicata, moral anthropology, to which the empirical principles belong. Moral anthropology is morality applied to men. Moralia pura is based upon necessary laws, and hence it cannot be founded upon the particular constitution of a rational being, such as man. The particular constitution of man, and the laws based upon it, come to the fore in moral anthropology under the name of ethics. ${ }^{25}$

Allen Wood nevertheless suggests that Kant's proposed metaphysics of morals, originally conceived to discern a priori laws of freedom, since it must contain "principles of application" can no longer dispense with moral anthropology-it now "includes some empirical anthropology." 26 Kant's metaphysics of morals thus, for Wood, becomes "a system of duties that results when the pure moral principle is applied to the empirical nature of human beings in general." 27

Wood's contention has an intuitive moral appeal. On one hand, it acknowledges the role that human nature plays in Kant's system of morals, without denying the metaphysics of morals its primordial goal-that of discerning the a priori laws of freedom. Instead, Wood's contention extends

${ }^{23}$ Kant, Metaphysics of Morals, 6:217. Emphasis mine.

${ }^{24}$ See Immanuel Kant, “Morality according to Prof. Kant: Lectures on Baumgarten's Practical Philosophy," in Lectures on Ethics, ed. by Peter Heath and J. B. Schneewind and trans. by Peter Heath (Cambridge: Cambridge University Press, 1997), 29:599.

${ }^{25}$ Kant, "Morality according to Prof. Kant," 29:599.

${ }^{26}$ See Wood, Kant's Ethical Thought, 195.

${ }^{27}$ Wood, Kant's Ethical Thought, 196.

(c) 2019 Dennis A. De Vera

https://www.kritike.org/journal/issue 25/de vera december2019.pdf

ISSN 1908-7330

(c) BY-NC-ND 
Kant's moral theorizing to include a system of duties that may be abstracted once human nature is understood, at least, in some respects. On the other hand, it recognizes the role of pure [practical] reason, indirectly at least, in the ordering of ends derived from the empirical character of moral anthropology, the source of duties, without losing its firm grip upon the a priori form of the moral law. Consequently, Kant's metaphysics of morals becomes not only a system of duties (ethics) but also a system of principles (morals) that articulates the purity of the moral law fitting for a human being regarded as free and autonomous.

Within the larger context of Kant's moral theorizing, this is consistent, in a fundamental way, with the primary aims of both the Groundwork and The Metaphysics of Morals. Initially, our understanding of human nature through moral anthropology leads us to our understanding of our duties (at least from our popular knowledge of ethics) derived from our common human experiences. We may refer to these duties as ends (not as moral ends though). ${ }^{28}$ These ends, however, since they are derived from empirical grounds, must be appropriately dealt with within the canons of the moral law itself. ${ }^{29}$ In other words, for these ends to be called "duties," they must be checked through the categorical imperative. This is essentially crucial since the very idea of "duty" in Kant's sense, cannot be determined by a prior external determination such as inclination, impulses or goods of prudence or what Kant himself calls "self-seeking ends." 30 Thus, the need for a transition from common rational cognition of morality to the more philosophic moral cognition. Secondly, our recognition of the role of moral anthropology in understanding Kant's ethics, articulates in effect, the universality of his moral philosophy. If the idea that a moral law holds for all human beings is true, then, its possibility stands or falls on whether or not it entails as well a universal concept of what a human being is-which is supplied, from common rational cognition, by moral anthropology. ${ }^{31}$ While it may be true for example that the origin of our moral concepts rests in reason and have their roots "completely a priori in reason," they require an object through which they can be applied, or in Kant's words, "it [metaphysics of morals] has to take as [its] object the particular nature of human beings." 32 Finally, our

${ }^{28}$ For nuances in meaning see Kant, Metaphysics of Morals, 6:381.

${ }^{29}$ Kant, Metaphysics of Morals, 6:381.

${ }^{30}$ Kant, Metaphysics of Morals, 6:383. Although in The Metaphysics of Morals, especially in the Doctrine of Virtue, Kant admits that there are indirect duties that we have to cultivate. For an interesting account of problematizing indirect duties, especially our indirect duty to cultivate sympathetic feeling, see Henry Allison, Kant's Theory of Taste: A Reading of the Critique of Aesthetic Judgment (Cambridge: Cambridge University Press, 2001), 229-235.

${ }^{31}$ Kant, Groundwork, 4:412.

32 Kant raises this point in both the Groundwork and The Metaphysics of Morals. See Groundwork, 4:412; Metaphysics, 6:217.

(c) 2019 Dennis A. De Vera

https://www.kritike.org/journal/issue 25/de vera december2019.pdf

ISSN 1908-7330

(cc) BY-NC-ND 


\section{A REREADING OF KANT'S ETHICS}

recognition of the role that moral anthropology plays in understanding the fundamental principles of morality does not simply point to the necessity of establishing the a priori character of moral laws themselves through an understanding of human nature. More than that, it points us to the more basic fact of our constitution as human beings: that we are free and autonomous, without which it becomes impossible for us to even recognize, let alone acknowledge, the need to be moral. In other words, we cannot act otherwise except through freedom. ${ }^{33}$ Thus, the need for a transition from the metaphysics of morals to the critique of practical reason.

We may ask: Why is such transition necessary? One modest response here is this: the transition to the critique of practical reason articulates the core features of Kant's ethics of autonomy. We can give two reasons why this is the case. On one hand, our humanity takes autonomy as the basis for legislating the moral law, the will being a "will giving universal law," ${ }^{34}$ by means of which we are necessitated to act, instead of being merely conditioned to. This, in effect, articulates the dignity that is due a rational being - how s/he makes use of freedom. ${ }^{35}$ On the other hand, it takes autonomy as well as a basis for an account of moral responsibility, being the sovereign author of the moral law itself. ${ }^{36}$ This is to say that as the sovereign author of the moral law: (a) we acknowledge the worth of humanity itself as an end and (b) we acknowledge that the basis of our actions are the rules we made for ourselves. ${ }^{37}$ In other words, our moral sense arises from our being able to legislate a law for ourselves and from our being conscious as its author. Interestingly, what this stresses is the priority of right over the more conventional concepts of both duty and good.

In the succeeding section, I lay down some considerations that may show how these two concepts may be developed so as to account for our moral sense. Indirectly, it also sketches some considerations why the idea of right (moral worthiness) is much more central to Kant's ethics than what a deontological reading tries to suggest. We may regard this account however as essentially methodological. The account though is based on John Rawls's appropriation of Kant's ethics.

\section{Autonomy and the Ideal of the Person}

How may the two concepts alluded to earlier account for our moral sense and thus lead to an understanding of the basis of our obligation to be

\footnotetext{
${ }^{33}$ Kant, Groundwork, 4:448.

${ }^{34}$ Ibid., 4:432

${ }^{35}$ Kant, “Notes on Moral Philosophy,” 19:181.

${ }^{36}$ Kant, Groundwork, 4:434.

${ }^{37}$ Kant, “Notes on Moral Philosophy," 15:521.
}

(C) 2019 Dennis A. De Vera

https://www.kritike.org/journal/issue 25/de vera december2019.pdf

ISSN 1908-7330

(c) BY-NC-ND 
moral? There are two possible suggestions here. The first is to try to begin with John Rawls's account of the Kantian ideal of the person. The second is to associate such ideal of the person to Kant's account of moral psychology. In my view, although Rawls's account is partly, strictly speaking, not Kant's, there are parallelisms evident in them, which makes it essentially Kantian. The term "reasonable" for example is not necessarily Kant's. John Rawls, however, takes this analogically as articulating the unity of pure practical reason-a unity that is based on the priority of right over the good. ${ }^{38}$ Or we may look at this as articulating what constitutes a morally worthy act instead of what may be a morally good act. Let me explain this further by going over Rawls's ideal of the person.

Central to John Rawls's appropriation of Kant's ethics is his Kantian reconstruction of the ideal of the person. He draws this ideal however from Kant's account of humanity. Here, the term humanity means "the powers that characterize human beings as reasonable and rational." 39 Rawls suggests that only these ideas articulate "a full-bodied conception" of Kant's vernünftig (reasonable). ${ }^{40} \mathrm{He}$ calls these powers the power of pure practical reason on one hand and the power of moral sensibility (which Kant calls moral feeling as it relates to feelings of pleasure and displeasure) on the other hand. ${ }^{41}$ Both powers, in Rawls's view, form the core features of a human being's moral personality, including, in addition, the power to set ends for oneself and for another as duties owed because of how a human being is constituted. ${ }^{42}$ The notion of moral personality here however, as Rawls suggests, points to a human being's freedom under the guidance of moral laws - that as a bearer of such moral personality, a human being is "subject to no other laws than

${ }^{38}$ John Rawls conjectures for instance that the term "reasonable" is drawn from Kant's distinction between the categorical and hypothetical imperatives as expressed in the Groundwork. They are "handy markers" to distinguish the two forms of practical reason: the pure and the empirical. I take the liberty of viewing it as central as well from the perspective of moral theorizing. See John Rawls, Political Liberalism (New York: Columbia University Press, 1993), 48 49 (see note); John Rawls, "Kantian Constructivism in Moral Theory," in John Rawls: Collected Papers, ed. by Samuel Freeman (Cambridge, MA: Harvard University Press, 1999), 319; John Rawls, "Themes in Kant's Moral Philosophy," in John Rawls: Collected Papers, ed. by Samuel Freeman (Cambridge, MA: Harvard University Press, 1999), 503-505.

${ }^{39}$ Rawls, "Themes in Kant's Moral Philosophy," 505.

${ }^{40}$ Ibid., 503.

${ }^{41}$ Moral feeling is also understood as susceptibility to feel pleasure or displeasure. Kant considers "feeling" here to be either pathological or moral. See Kant, Metaphysics of Morals, 6:399. In another important work, Kant views moral feeling as "receptivity" when one finds oneself subject to the unconditional necessitation of the [moral] law. See Immanuel Kant, "On the common saying: That may be correct in theory, but it is no use in practice," in Practical Philosophy, trans. and ed. by Mary J. Gregor and Allen Wood (Cambridge: Cambridge University Press, 1996), $8: 284$.

${ }^{42}$ Kant, Metaphysics of Morals, 6:392-6:394. 


\section{A REREADING OF KANT'S ETHICS}

those he gives to himself." 43 Let me unpack each of these moral powers of the moral personality, though briefly, one after another.

A first fundamental idea in Rawls's characterization of the moral personality is the power of pure practical reason. Rawls looks at pure practical reason as essentially articulated by the concepts of the "reasonable" and the "rational." 44 In Rawls's original formulation, the idea of the reasonable means, on one hand, "the willingness to propose fair terms of cooperation and to abide by them willingly" and, on the other hand, "the willingness to recognize the burdens of judgments and accept their consequences." 45 The idea of the rational, however, is the opposite-although they are willing to engage in cooperative schemes, they are unwilling to honor the fair terms of cooperation. What the idea of the rational lacks here, in other words, is the objectivity of the reasonable or the underlying principle that compels persons to engage in a system of fair cooperation in terms that all can readily accept. One way perhaps to understand the distinction is to try to associate them, as Rawls does, with the categorical and hypothetical imperatives or with both autonomy and heteronomy of reason. ${ }^{46}$ As earlier mentioned, Rawls suggests that the idea of the reasonable is expressed by pure practical reason, while the

${ }^{43}$ Ibid., 6:224.

${ }^{44}$ Rawls's use of the ideas of the reasonable and the rational are purposely conceived, in a narrower sense, to fit the context of his political conception of justice. In Political Liberalism, Rawls uses these ideas narrowly to describe the powers of "citizens" in a democratic society, instead of the broader term persons. See Rawls, Political Liberalism, 48-54.

${ }^{45}$ Rawls, Political Liberalism, 49f.

${ }^{46}$ In Kant's view, the autonomy of reason, if reason were to be self-determining or autonomous, must conform to the categorical imperative. It may be recalled for example that the categorical imperative is the only command of morality which reason must consent to unconditionally, owing to what it represents - the objectivity of the moral law and the autonomy of the will. Roughly construed, the idea here is this: since the will is viewed as a will-giving universal law, it must be capable of imposing constraints universally - that it must hold for all. Or we may think of this conformity as articulating our obedience to the form of a law independent of its matter. We may think of this conformity to the categorical imperative as expressing the causal independence of reason from inclinations or interests.

The underlying context here is this: as rational beings, we are part of nature that works according to laws, yet, as rational beings, we also have the capacity to act in accordance with laws or principles - that we have a will. Our will however can be necessitated to act either categorically or hypothetically. If the act stems from a good will, the necessitation is categorical. At one point, an act that stems from a good will is, undoubtedly, good without qualification. At another point, an act that stems from a good will is good in itself. If the act stems not from good will, then, it is hypothetical. It is precisely for this reason that hypothetical imperatives (imperative of skills and counsels of prudence), although they arise from practical reason, while good, do not possess the objectivity and the unconditional necessity of the categorical imperative. They are determined by prior pathological conditions, which make them only conditionally good and thus are heteronomous. We may think of hypothetical imperatives as expressing our dependence on external causes - that although good, they are simply means to achieve some desired ends. See Kant, Groundwork, 4:413.

(c) 2019 Dennis A. De Vera

https://www.kritike.org/journal/issue 25/de vera december2019.pdf

ISSN 1908-7330

(cc) BY-NC-ND 
rational is expressed by empirical practical reason. At the risk of appearing simplistic, we may put forward three ways to see how this is the case.

Firstly, we may ask: what is it that the reasonable seeks to articulate to represent pure practical reason? We may answer in the following manner: the reasonable articulates a form of objectivity that may be shared by all. ${ }^{47}$ It seeks to establish a frame of thought (echoing Rawls) that may provide the basis for universal agreement (echoing Kant), i.e., a framework of thought that may specify, in a fundamental way, the kinds of reasons, judgments, decisions, and modes of deliberation, that all may possibly agree to. Similarly, it seeks to specify as well the reasons why we must consent to them or how we are better able to give them due considerations as the sort of reasons worthy of our assent. A case in point here for instance is the fundamental principle of the "right to life." Not only does it specify a frame of thought that all may possibly agree to, it also specifies the kinds of reasons why we must regard it as essentially fundamental. As a frame of thought, the "right to life" holds true for all. It does not discriminate anyone. It holds even to those who disregard its fundamental import as a morally binding principle fitting to all persons. That, even if it were perpetually under-fulfilled, if not violated, its formulation remains true and holds true for all persons. In other words, akin to pure practical reason, the reasonable is not only unconditional but also objectively necessary. In contrast, although the rational is also a frame of thought, it lacks the objectivity of the reasonable. On one hand, it is not broadly shareable. The kinds of reasons it specifies, perhaps, are fundamentally subjective and do not hold true for all. On the other hand, it lacks "moral sensibility" (to use Rawls). ${ }^{48}$ What it seeks to establish may perhaps be limited only to some particularistic benefits or ends derived from self-interests. Or we may, by way of analogy, think of the rational as seeking to establish a frame of thought determined by some pre-conceived object of desire or good (perhaps material determining ground), which, while beneficial, does not hold true for all (echoing heteronomy of reason). ${ }^{49}$

A second way of looking at the distinction is by way of asking: to what sort of end is the reasonable responding to such that it articulates the interest of pure practical reason? A brief answer is this: the reasonable seeks to achieve a kind of ideal similar to a Kantian realm of ends by desiring a common social world for its own sake. ${ }^{50}$ The underlying motivation here is

\footnotetext{
${ }^{47}$ I have been influenced to look at objectivity in this manner owing to Rawls's three conceptions of objectivity. See Rawls, Political Liberalism, 110-112.

${ }^{48}$ Rawls, Political Liberalism, 51.

${ }^{49}$ Kant, Groundwork, 4:441; see also Critique of Practical Reason, 5:40-5:41.

${ }^{50}$ I took the liberty of combining two ideas here. Rawls's social world and Kant's realm of ends. See Rawls, Political Liberalism, 50, Rawls, Lectures on Moral Philosophy, 164-166; Kant, Groundwork, 4:433.
} 


\section{A REREADING OF KANT'S ETHICS}

expressed by the frames of thought that the reasonable seeks to establish in order to build a social world governed by laws that all can agree to and share with. What drives this desire perhaps is the belief in the dignity that is due a human being as free and autonomous. Since, in Kant's view, a human being is regarded either as a member or as a sovereign, as s/he is able to claim authorship to any frame of thought, it is but [morally] fitting to suppose that $\mathrm{s} /$ he serves as the ultimate limiting condition from which all frames of thought must defer. Kant for example aptly writes:

a human being alone, and with him every rational creature, is an end in itself: by virtue of the autonomy of his freedom he is the subject of the moral law, [...]. Just because of this every will, even every person's own will directed to himself, is restricted to the condition of agreement with the autonomy of the rational being, [...] hence this subject is to be used never merely as a means but as at the same time an end. We rightly attribute this condition $[\ldots]$, inasmuch as it rests on their personality, by which alone they are ends in themselves. ${ }^{51}$

This reechoes for example Kant's formula of humanity where a rational agent is viewed as an end-in-itself-that there is no other end more valuable than humanity itself. Precisely because humanity is viewed as the supreme limiting condition of all possible practical laws, its primary purpose then is no other than the advancement of humanity for its own sake. Again, the fundamental principle of the "right to life" may serve as an illustrative example pertinent to this point. Its merit, as a fundamental principle, is not determined by any other arbitrary end than the dignity that is due a human being, that it is desired for humanity's own sake. In contrast, the rational lacks the dignifying condition of the reasonable, in that it is primarily motivated by ends which are in themselves arbitrary and which may in fact be used against humanity itself as a means to advance some desired ends. That said, what underlies the rational is a frame of thought grounded upon a set of selfseeking ends.

Finally, we may, based on the desire to achieve a common social world, look at the distinction as a way of establishing a coherent system of practical laws founded on our belief in the possibility of Kant's realm of ends. The reasonable, in this regard, seeks to bring, a la Kant, the diverse frames of thought that divide human beings, nearer to intuition (or shall we say our

${ }^{51}$ Kant, Critique of Practical Reason, 5:87. Emphasis mine. The same thought for instance is expressed in the Groundwork: "... the end must here be thought $[\ldots]$ as an independently existing end, $[\ldots]$, that which must never be acted against [...]" Kant, Groundwork, 4:438.

(c) 2019 Dennis A. De Vera

https://www.kritike.org/journal/issue 25/de vera december2019.pdf

ISSN 1908-7330

(cc) BY-NC-ND 
common rational cognition of our social world). A key idea here may be that of moral deliberation where various frames of thoughts, including its reasons, judgments, and decisions, are carefully examined and rigorously scrutinized under a coherent frame of moral appraisal - the purpose of which is to arrive at some shareable frame of thought that may be made the basis for adopting a [practical] law for all human beings, if not facilitate, its possibility. Or it may even begin, in fact, from what Kant considers sensus communis because of its capacity to feel (sense) what is universally communicable and shareable. ${ }^{52} \mathrm{As}$ a sense common to all for example, it may facilitate the determination, if not juxtaposition, of various inclinations, interests, or temptations that hinder the process of a reasoned moral consensus, in order to arrive at some consistent maxims, precepts, or principles preparatory for a common human understanding. ${ }^{53}$ Such that, on the basis of this determination through the sensus communis, prejudiced thinking (heteronomy of reason) may be avoided to give way to the more enlightened form of thinking (autonomy of reason) that may be shared by all. A closest example here for instance may be the system of moral human rights we now have: an artifice of reason at that, par excellence.

A second fundamental characterization of our moral personality is the power of moral sensibility (what Kant himself refers to as [moral] feeling). In Rawls's view, the power of moral sensibility are moral endowments that are intrinsic to the constitution of a person owing to his/her moral personality they are natural predispositions (to use Kant) that allow us to be aware of or even affected by concepts of duty or even by concepts of obligation. In The Metaphysics of Morals, Kant notes that they are "subjective conditions of receptiveness to the concept of duty" and thus stand at the base of morality. ${ }^{54}$ This is to say that our appreciation, let alone recognition, of the notions of moral goodness and its opposite, or those notions of good manners and right conduct, that are either in conformity with or in violation of [ethical/moral] laws, are made possible through moral sensibility. It is important to note nevertheless, that although moral sensibility makes us aware of, or even susceptible to, these so called "duties," it is by no means a prior determining ground of such awareness, but rather an effect of the determination of the will. ${ }^{55}$ In other words, the dialectic of moral sensibility remains dependent

52 See Immanuel Kant, Critique of the Power of Judgment, ed. by Paul Guyer and trans. by Paul Guyer and Eric Matthews (Cambridge: Cambridge University Press, 2000), 5:293-5:295. See also Allison, Kant's Theory of Taste, 148-149.

${ }^{53}$ A corollary idea here (sensus communis) developed by Kant are the maxims for common human understanding, the purpose of which is in fact to arrive at some form of consistent way of thinking on the basis of some criteria that are shareable and communicablean enlightened thinking. Kant, Critique of Judgment, 5:294.

${ }^{54}$ Kant, Metaphysics of Morals, 6:399.

${ }^{55}$ Kant, “On the common saying," 8:283. 


\section{A REREADING OF KANT'S ETHICS}

upon, if not subject to, the determination of the will as an objective determining ground of any imperative of morality. That, while it is possible that moral sensibility makes us aware of the [practical] necessity of doing an action, let alone be moved by it, owing to what it elicits in us (a certain moral feeling of either praise or blame perhaps), how we determine our choices of actions, or how we respond to it, remains subject to the autonomy of the will itself. For instance, while lying elicits in us a certain feeling of reprobation, what determines its moral worthiness or unworthiness as an act, in an essential way, is not the [moral] feeling that it elicits (which may be good) but rather its conformity with the law that forbids or prohibits lying (moral worthiness). ${ }^{56}$ Again, while it may be true that moral sensibility makes us aware of certain moral feelings, whether of approbation or reprobation, its primary purpose is directed at the autonomy of the will so that we may be disposed to act in conformity with what pure practical reason directs us to do and bind ourselves with it-our obedience to the moral law. ${ }^{57}$

Rawls nevertheless, remarks that these moral powers "make a good will and moral character possible," that is, that "we have a duty to cultivate them [our natural capacities] in order to make ourselves worthy of our humanity." 58 The underlying reason here is given by the idea that they may come useful to reason later on. Let me quote Kant at length:

A human being has a duty to himself to cultivate (cultura) his natural powers [...] as means to all sorts of possible ends. - He owes it to himself (as a rational being) not to leave idle and, as it were, rusting away the natural predispositions and capacities that his reason can someday use. [...] Hence, the basis on which he should develop his capacities (for all sorts of ends) is not regard for the advantages that their cultivation can provide; [...] Instead, it is a command of morally practical reason and a duty of a human being to himself to cultivate his capacities. ${ }^{59}$

The duty of cultivation nonetheless of the moral powers that we have, including the duty to cultivate our natural moral endowments, constitutes, in

${ }^{56}$ In "Notes on Moral Philosophy" Kant writes however: "The doctrine of moral feeling is more a hypothesis to explain the phaenomenon of approbation that we give to certain actions than anything that should firmly establish maxims and first principles that are objectively valid concerning how one should approve or reject something, act or refrain from acting." See Kant, "Notes on Moral Philosophy," 19:116-117.

${ }^{57}$ Here I take note of some of Henry Allison's account of moral feeling as he contrasts it with the feeling of the sublime. See Allison, Kant's Theory of Taste, 324-326.

58 Rawls, "Themes in Kant's Moral Philosophy," 505.

${ }^{59}$ Kant, Metaphysics of Morals, 6:445. Emphasis mine.

(c) 2019 Dennis A. De Vera

https://www.kritike.org/journal/issue 25/de vera december2019.pdf

ISSN 1908-7330

(cc) BY-NC-ND 
a general way, our commitment towards moral perfection. While it may be true for example, as Kant argues, that such level of cultivation remains in a state of perpetual "striving," in so far as human life is unfathomable, it remains a duty owed to ourselves that we have to cultivate nevertheless, that [pure practical] reason consents to, so that we may become, eventually, "useful members of the world" whose dignity must never be degraded. ${ }^{60}$ In the same way, this striving for moral perfection is pursued so that we may, in an essential sense, remain firmly grounded on our commitment to secure, if not sustain, the moral ends that we set for ourselves against the pathologies of our sensuous nature. This is to say that it is our duty to "bring all [our] capacities and inclinations under [our reason's] control and so rule over ourselves" in order that "our feelings and inclinations will not play master over ourselves." ${ }^{61}$ More than this though, it is our positive duty we must pursue as sovereign authors of [practical] principles, if not laws, so that we may, in the best way possible, "restore the purity of the moral law" in us, in so far as it is the supreme ground of all our moral maxims, as the sole selfsufficient incentive of the autonomy of our will. ${ }^{62}$

The idea of restoring the purity of the moral law as well as the striving for moral perfection on the contrary, may perhaps be understood better if situated within the context of our human nature or within the context of what Rawls calls Kant's Augustinian moral psychology. ${ }^{63}$ Let me briefly describe though why there is a necessity to develop our moral powers within this context.

In Religion within the Boundaries of mere Reason, Kant enumerates three natural predispositions that our human nature has. ${ }^{64}$ These predispositions are in themselves original in us, i.e., they are innate characteristics of a human being. Firstly, there is the natural predisposition to animality as a living being. In Kant's view, this natural predisposition is directed at (a) self-preservation, (b) preservation and propagation of the human species, and (c) social communion. Secondly, there is the natural predisposition to humanity as a rational human being. This is primarily characterized by self-love, the origin of our inclination to gain either equal worth or superiority over others. Finally, there is the predisposition to personality as an accountable and responsible human being or as Henry Allison puts it, a "being whom reason is practical of itself." 65 In Rawls's view, our predisposition to personality has two

\footnotetext{
${ }^{60}$ Ibid., 6:446. Emphasis mine.

${ }^{61}$ Ibid., 6:408.

${ }^{62}$ Kant, Religion within the boundaries of mere Reason, 6:46.

${ }^{63}$ Rawls, Lectures on Moral Philosophy, 291.

${ }^{64}$ Kant, Religion within the boundaries of mere Reason, 6:26-6:28.

${ }^{65}$ Allison, Essays on Kant, 101.
} 


\section{A REREADING OF KANT'S ETHICS}

fundamental aspects. ${ }^{66}$ On one hand, it enables us to view the moral law, as reasonable and rational, as an idea of pure practical reason. On the other hand, it enables us to respect the moral law as an incentive itself for our free power of choice. Rawls however is quick to add that in the absence of moral feeling, it is not even possible for us to be motivated to act (through moral feeling) in conformity with the moral law (respect for the moral law as an idea of pure practical reason). Rawls however argues that among the natural predispositions, it is "this" predisposition that "we cannot repudiate" and "that we cannot exempt ourselves from the moral law" - being the sufficient determining ground of our will (self-sufficient incentive). ${ }^{67}$ Be that as it may, Kant interestingly characterizes this natural predisposition to personality as our "susceptibility" to respect the moral law (Rawls's first aspect) in us through our moral feeling (Rawls's second aspect) - as an incentive that we incorporate to the power of choice-something that is added to our predisposition to personality. ${ }^{68}$ In Kant's view, it is by virtue of this predisposition, along with the moral feeling that we incorporate into the maxims of freedom, that we are capable of either good or evil. In general though, these three natural predispositions are all predispositions towards good, in so far as they are not antagonistic to and are deferent with the moral law itself.

On the contrary, although they are all predispositions towards the good, they are also capable of effecting the will (through motivation) to deviate from the moral law owing to human nature's natural propensity to evil.69 In Kant's view, this natural propensity to evil arises because of the frailty, impurity, and depravity of our human nature. ${ }^{70}$ This propensity to evil gives rise to our deviation from, if not violation of, the moral law when we are motivated to incorporate into our maxims any of those inclinations, desires, and temptations that we have (owing to our natural predispositions). ${ }^{71}$ In other words, when the will, owing to our propensity to evil, is influenced to choose a maxim defined by a prior ground and determines itself (external incentive such as inclination to wealth, interest to fame/honor, or desire for physical pleasure) other than the moral law, our

${ }^{66}$ Rawls, Lectures on Moral Philosophy, 292.

67 Ibid., 295.

${ }^{68}$ Kant, Religion within the boundaries of mere Reason, 6:28.

${ }^{69}$ Ibid., 6:29.

${ }^{70}$ Ibid., 6:30

71 This is not to say that we are motivated to do evil for evil's sake. Instead, we do not see our conformity to the moral law as a positive incentive. Given that our propensity to evil is "innate" in our human nature, it can also be socialized or socializing. Allen Wood refers to this as "unsociable sociability" developed through the course of historical human relations. Wood, Kant's Ethical Thought, 213-215. Henry Allison though provides a contrasting view by distinguishing two notions of our propensity to evil. Allison, Essays on Kant, 107.

(C) 2019 Dennis A. De Vera

https://www.kritike.org/journal/issue 25/de vera december2019.pdf

ISSN 1908-7330

(cc) BY-NC-ND 
[pure practical] reason becomes heteronomous and denies itself its own capacity to be self-determining or autonomous. That, while it remains good, in a general way, the resulting act loses its moral worthiness as an autonomous moral act. How then do we reconcile the autonomy of our will, our natural predispositions to good, and this radical evil in our human nature? In Kant's view, these can be resolved only through moral education and ever-continuing striving for the better-our moral vocation to build an essentially good character worthy of our humanity. Kant of course best explains the answer:

For the judgment of human beings, however, who can assess themselves and the strength of their maxims only by the upper hand they gain over the senses in time, the change is to be regarded only as an ever-continuing striving for the better, hence as a gradual reformation of the propensity to evil, of the perverted attitude of mind. From this it follows that a human being's moral education must begin, not with an improvement of mores, but with the transformation of his attitude of mind and the establishment of a character...72

What underlies this moral education though, aside from the reconciliation that it seeks to achieve and the purity of the moral law that it seeks to restore, is no other than our concept of freedom, which we infer and discover from our immediate consciousness of the moral law itself-"our original moral predisposition" through practical reason. ${ }^{73}$ This is to say that our striving for moral perfection through our chosen means of moral education is no other than our striving to achieve the spontaneity of our freedom, akin to the absolute spontaneity of our [pure practical] reason. This is essentially crucial since what the moral law seeks to articulate is no other than the autonomy of pure practical reason itself, i.e., freedom-the formal condition of all maxims. ${ }^{74}$ That, although it may be influenced by factors other than those it gives to itself (imperative of skills or counsel of prudence) or those that may be derived from the natural predispositions for instance, it may also determine for itself, spontaneously, a set of moral ends and frame them according to their practical necessity, either in conformity with duty or for the sake it. ${ }^{75}$ In Rawls's view, this spontaneity of freedom [practical reason] manifests itself in the way we arrange our predispositions according to the moral order we act from, owing to our moral personality, whose essential

\footnotetext{
${ }^{72}$ Kant, Religion within the boundaries of mere Reason, 6:48. Emphasis mine.

${ }^{73}$ Ibid., 6:49. Emphasis mine.

${ }^{74}$ Kant, Critique of Practical Reason, 5:33.

${ }^{75}$ Rawls, Lectures on Moral Philosophy, 284.
} 


\section{A REREADING OF KANT'S ETHICS}

nature is to be immediately conscious of the moral law. ${ }^{76}$ Such that if it were true that it is by means of freedom that we deviate from the moral law, then, it is also true that it is only through freedom that can we restore the purity of the moral law itself, provided that we achieve the spontaneity of freedom through our moral striving.

In the section that follows, I lay down two suggestions, based on the aforementioned, to illustrate some considerations why we owe our obligation to be moral (moral sense) to our humanity. I suggest initially that our humanity takes autonomy as the basis of authority for legislating the moral law. Then, I suggest secondly as well, that our humanity takes our autonomy as a basis for a satisfactory account of moral responsibility. These two points suggest that our obligation to be moral arises, in fact, from the moral principles that we give to ourselves through our practical reason.

\section{Appropriating Moral Sense: A Rereading of Kant's Ethics}

The preceding section outlines a close approximation of the conceptual elements that we need to respond to the question "To whom do we owe our moral sense?" While they are able to provide hints, in a fundamental way, as to what may be a possible good answer, they also provide clues to the contrary. The natural propensity to evil, for example, notwithstanding our natural predispositions towards the good, complicates this point even further. Whether or not it is indeed possible to reconcile them through the autonomy of the will is an important philosophical question that remains puzzling even among contemporary Kant scholars. However, from a practical point of view, Rawls's appropriation of Kant's ethics seems to suggest another way out. Consistent with Kant's writings, he provides an alternative reading that may shed light to the seemingly irreconcilable difference between our natural predispositions and our natural propensity to evil. In my view, what Rawls offers is a form of moral theorizing (not a theory) which may be possibly called Kant's ethics of autonomy, whose starting point rests upon our humanity - our moral personality. Briefly put, our humanity is the basis of our moral sense and our moral responsibility. Let me however remark at the outset that this reading takes the following points as fundamental assumptions: Initially, it presupposes pure practical reason as fact of reason. Secondly, it takes both natural predispositions toward the good and natural propensity to evil as part of our moral personality. Thirdly, it regards moral worthiness as a defining characteristic of any moral act as it gives importance to the restoration of the purity of the moral law. Finally, it emphasizes the role of moral cultivation or moral striving towards moral perfection as a way

${ }^{76}$ Ibid., 306.

(c) 2019 Dennis A. De Vera

https://www.kritike.org/journal/issue 25/de vera december2019.pdf

ISSN 1908-7330

(cc) BY-NC-ND 
of balancing out the seeming inconsistent features of human nature between natural predispositions and our natural propensity to evil. In general however, Rawls's appropriation of Kant's ethics offers a constructive moral ground-a moral landscape where both may be possibly reconciled, the construction of which provides the necessary background material to respond to the question "to whom do we owe our moral sense." Let me then offer some reflections to show how the question may be responded to.

At the outset, I mentioned that we owe our moral sense to our humanity for two reasons. On one hand, our humanity takes autonomy as the basis of authority for legislating the moral law. On the other hand, our humanity takes our autonomy as a basis for a satisfactory account of moral responsibility. An important consequence of these reasons is that it enables us to discern the moral worthiness or rightness of a given act through the autonomy of the will - the ultimate object of the moral law. At this juncture, let me give some considerations as to how these reasons may account for our moral sense.

We may begin with the idea that there arises a moral sense in us owing to our autonomy as the basis of authority for [legislating] the moral law. ${ }^{77}$ Here, our moral sense is our capability to discern whether or not a given act is morally worthy. The notion of discern here, however, is practically grounded upon and is suggestive of our natural predisposition to personality (as reasonable and rational). I begin with this idea in order to see whether or not autonomy may indeed be that basis. I suggest nevertheless that we may possibly give a rough approximation as to how it may be possible. Consider for instance the following passages from Kant's various writings:

1. Thus the moral law expresses nothing other than the autonomy of pure practical reason, that is, freedom, and this is itself the formal conditions of all maxims, under which alone they can accord with the supreme practical law.78

2. The will is not merely subject to the law but subject to it in such a way that it must be viewed as also giving the law to itself, and just because of this as first subject to the law (of which it can regard as the author). ${ }^{79}$

77 The manner of presentation here reflects the influence of Rawls's presentation of the fact of reason as he tries to deduce that the fact of reason is no other than our consciousness of the moral law as supremely regulative and authoritative for us. Rawls, Lectures on Moral Philosophy, 258-261.

${ }^{78}$ Kant, Critique of Practical Reason, 5:33. Emphasis mine.

${ }^{79}$ Kant, Groundwork, 4:431. 


\section{A REREADING OF KANT'S ETHICS}

3. Morality is thus the relation of actions to the autonomy of the will, that is, to a possible giving of universal law through its maxims. An action that can coexist with autonomy of the will is permitted; one that does not accord with it is forbidden. ${ }^{80}$

4. Pure practical reason [...] can determine the will - and it does so by a fact in which pure reason in us proves itself actually practical, namely the autonomy in the principle of morality by which reason determines the will to deeds. ${ }^{81}$

5. We can quickly be convinced that the concept of freedom of the power of choice does not precede in us the consciousness of the moral but is only inferred from the determinability of our power of choice through this law as unconditional command. We have only to ask whether we are certainly and immediately conscious of a faculty enabling us to overcome, by firm resolve, every incentive to transgression, however great. ${ }^{82}$

Passages 1-4 articulate one central idea - the moral law presupposes autonomy of the will, whether in matters of formulation (1-2) or in relationsas to prohibition and permissibility (3) and even in its determination (4). Passage 5, while formulated differently, expresses nonetheless the same thing as if suggesting that our consciousness of the moral law is at the same time a consciousness of an enabling faculty, which I read, as referring to our autonomy in so far as it is intrinsic to our natural predisposition to personality-as part of our moral personality.

It is possible, on the contrary, to view each of these passages as essentially articulating different points or to view them as stand-alone passages. But such possibility seems too remote primarily because in all passages, reference is made to autonomy as primordial to the articulation of the moral law and central in the formulation of maxims that may be made into practical laws provided that they cohere with the autonomy of the willbeing their formal condition which allows maxims to conform to or be in accord with the supreme practical law. Or it is also possible to take them as selective applications of passages to fit a preconceived idea of how our moral sense arises in us. But this may be easily dispensed with on the basis of passage 5, which articulates how our consciousness of the moral law leads us to our awareness of our autonomy as a fact of reason. ${ }^{83}$ Ceteris paribus, we may

\footnotetext{
${ }^{80}$ Ibid., 4:439.

${ }^{81}$ Kant, Critique of Practical Reason, 5:42. Emphasis mine.

${ }^{82}$ Kant, Religion within the boundaries of mere Reason, 6:50n. Emphasis mine.

${ }^{83}$ Kant, Critique of Practical Reason, 5:31.
}

(C) 2019 Dennis A. De Vera

https://www.kritike.org/journal/issue 25/de vera december2019.pdf

ISSN 1908-7330

(c) $)$ BY-NC-ND 
then provide a shared formulation of the abovementioned passages in this way:

Our moral personality is so constituted the way it is that it enables us to discern the moral worthiness of an act or its opposite, through the autonomy of our will, being the basis of authority of [legislating] the moral law as a formal condition and the sole articulation of the purity of the moral law itself.

The idea here is to bring together the relevant features that make moral sense possible. We may, in some respects, provide a coherent view of this possibility on the basis of the following points.

Firstly, our moral personality consists of predispositions that enable us to understand the moral law as an idea of pure practical reason and respect the moral law as of itself a sufficient moral incentive for the autonomy of our will. This is the same as saying that there is, in us, an intrinsic capacity that allows us to discern whether or not a given moral law is respectable or practically necessary. We may suggest then, owing to this discerning ability, that there is, in us, an innate capacity for moral sense.

Secondly, our moral personality possesses as well an incomprehensible enabling faculty that we become immediately conscious of, owing to our consciousness of the moral law itself. This enabling faculty is what determines our moral ends and how we arrange them on the basis of their practical necessity for us. We may suggest then, that our moral sense presupposes this enabling faculty in its determination of our moral ends.

Thirdly, our moral personality is constituted for only one end - that of achieving moral perfection through the restoration of the purity of the moral law in us. The purity of the moral law, however, is possible only in so far as our will is autonomous. There is autonomy of the will though when "it is not necessitated to act through any sensible determining grounds." 84 This on the contrary demands discernment, since we have no direct intuition of freedom. We may suggest thus that our moral sense is a discernment towards achieving autonomy.

Finally, our moral personality may be motivated to act either internally (inner freedom) or externally (outer freedom). ${ }^{85}$ On one hand, there is internal motivation through respect of the moral law as the sole moral incentive itself. To be internally motivated to act is to be autonomous - it is our freedom under the guidance of moral laws. On the other hand, there is external motivation

\footnotetext{
${ }^{84}$ Kant, Metaphysics of Morals, 6:226.

${ }^{85}$ Kant, Critique of Practical Reason, 5:161.
} 


\section{A REREADING OF KANT'S ETHICS}

through inclinations that arise from our natural dispositions. To be externally motivated is to be heteronomous. What the moral law expresses though is nothing other than (inner) freedom "under which alone maxims may be in accord with the supreme practical law." 86 We may suggest then, that since it is only through freedom that maxims may be in accord with the supreme law, freedom or autonomy may be made the basis of authority for legislating the moral law.

We may conclude therefore, based on the aforementioned, that our moral personality is so constituted the way it is that it enables us to discern the moral worthiness of an act or its opposite, through the autonomy of our will, being the basis of authority of [legislating] the moral law, as a formal condition of all maxims and the sole articulation of the purity of the moral law itself. Given the natural predispositions that we have and the weakness of our nature as human beings, it is only through the exercise of our autonomy that we may possibly regain the dignity that is due ourselves as autonomous human beings with moral personalities. Let me however quote Kant at length to amplify, in an indirect way, how this point may be made relevant. In the Doctrine of Method of the second Critique for instance, Kant writes:

The heart is freed and relieve of a burden that always secretly presses upon it, when in pure moral resolutions, examples of which are set before him, there is revealed to the human being an inner capacity not otherwise correctly known by himself, the inner freedom to release himself from the impetuous importunity of inclinations so that none of them, not even the dearest, has any influence on a resolution for which we are now to make use of our reason. [...] and this includes consciousness of an independence from inclinations and from circumstances and of the possibility of being sufficient to myself, which is salutary to me in general, in other respects as well. And now the law of duty, through the positive worth that observance of it lets us feel, finds easier access through the respect for ourselves in the consciousness of our freedom. When this is well established, [...] then every good moral disposition can be grafted onto it, because this is the best, and indeed the sole, guard to prevent ignoble and corrupting impulses from breaking into the mind. ${ }^{87}$

${ }^{86}$ Ibid., 5:33.

${ }^{87} \mathrm{Ibid} .$, 5:161. Emphasis mine.

(c) 2019 Dennis A. De Vera

https://www.kritike.org/journal/issue 25/de vera december2019.pdf

ISSN 1908-7330

(c) BY-NC-ND 
A corollary idea that is developed here, interestingly, is the idea of moral responsibility. Early on, I mentioned that our humanity takes autonomy as a basis for providing a satisfactory account of moral responsibility. In the history of British moral philosophy, the idea of moral responsibility is usually associated with the notions of praise and blame. ${ }^{88}$ Christine Korsgaard, on the other hand, seems to suggest that, in Kant's moral writings, moral responsibility is closely associated with rational agency - that it "arises from the perspective of the agent who is deciding what to do." ${ }^{89}$ A contrary view though is found in Peter Strawson's Freedom and Resentment, where he seems to suggest that the locus of moral responsibility rests upon "the fact of our natural human commitment to ordinary inter-personal attitudes," thereby echoing a determinist view of moral responsibility. ${ }^{90}$ Whether moral responsibility arises in us, through our agency or it arises outside us, through external determining causes, is a complex issue even in contemporary literatures on moral philosophy. Despite that, it is important to note that the question concerning moral responsibility is as crucially important as the questions surrounding the old-age problem of free will and determinism. It is not my intention though to address both. Instead, I lay down some ways that may give considerations as to why, owing to our moral personality, we may be held morally responsible or personally accountable. By going over Kant's account of the autonomy of the will and its connection to the moral law, we hope to shed some light on this point.

Consider the following passages in Kant's works:

(1) [As an auctor], it is [b.] absolutely necessary in addition, that he act with freedom, indeed it is only when considered as a free being that he can be accountable. For it is from laws of freedom that the duties arise, which he can fulfil or violate, and only to that extent is his action independent of nature. ${ }^{91}$

(2) Moral failures of all kinds, from the lesser ones of fragility and impurity to the worst extremes of wickedness and perversity of which we are capable, must all arise, not from the desires of physical and social nature, but solely from our exercise of our

\footnotetext{
${ }^{88}$ Korsgaard, Creating the Kingdom of Ends, 189.

${ }^{89}$ Ibid.

${ }^{90}$ See Peter Strawson, "Freedom and Resentment," in Free Will, ed. by Gary Watson (Oxford: Oxford University Press, 2003), 83.

${ }^{91}$ Immanuel Kant, "Kant on the Metaphysics of Morals: Vigilantus' Lecture Notes," in Lectures on Ethics, ed. by Peter Heath and J. B. Schneewind and trans. by Peter Heath (Cambridge: Cambridge University Press, 1997), 27:559.
} 
free power of choice. And for this exercise we are held fully accountable. ${ }^{92}$

(3) The moral law commands compliance from everyone, and indeed the most exact compliance. ${ }^{93}$

(4) Consciousness of the fundamental moral law [...] forces itself upon us of itself as a synthetic a priori proposition. ${ }^{94}$

(5) He judges, therefore, that he can do something because he is aware that he ought to do it and cognizes freedom within him, which, without the moral law, would have remained unknown to him. ${ }^{95}$

We may think of these passages as possible pointers that may give hints as to how we may be made morally responsible. While we may think of them as too few and perhaps may not provide sufficient grounds to account for moral responsibility, we may nevertheless consider what commonalities they have which may be useful for our accounting of moral responsibility.

Passages 1 and 2 reference an element (if we may call it that) of moral responsibility - the element of freedom. One underlying reason here perhaps is the idea of an auctor (originator). Passages 3 and 4 suggest as well another element of moral responsibility - that there must be a command that is able to force itself upon us unconditionally. Passage 5 seems to add an element of judgment, which I read as referring to our personal appraisal as to whether it (command) "can" (freedom) be brought about. We may suggest then that there arises moral responsibility on the condition that there is an auctor (agent), a command and an appraisal of what it is that is brought about. Ceteris paribus, we may perhaps consider moral responsibility as follows:

Our moral personality is so constituted the way it is that it holds us morally responsible for the fulfilment of or violation of the principles, maxims or laws that we ourselves regard as morally permissible, if not morally obligatory.

${ }_{92}$ This is a paraphrase made by Rawls. See Rawls, Lectures on Moral Philosophy, 294. The original text is in Kant, Religion within the boundaries of mere Reason, 6:30.

${ }^{93}$ Kant, Critique of Practical Reason, 5:36.

${ }^{94}$ Ibid., 5:31.

${ }^{95}$ Ibid., 5:30.

(C) 2019 Dennis A. De Vera

https://www.kritike.org/journal/issue 25/de vera december2019.pdf

ISSN 1908-7330

(c) BY-NC-ND 
Again, the idea here is to bring together what may be possibly called hints that may suggest how we can be made morally responsible. We may perhaps consider the following points in order to see whether or not we can give a coherent view of this formulation.

Firstly, intrinsic to our moral personality, in a general way, is an enabling faculty called freedom. Our freedom may be motivated to act either internally or externally. We are autonomous or self-determining when we are motivated to act internally. We are heteronomous if otherwise. Since an element of moral responsibility is the fulfilment of certain principles or commands we ourselves regard as morally obligatory or permissible, it follows that moral responsibility may be attributed to us only when such principle or command is brought into fulfilment.

Secondly, intrinsic to our moral personality as well is our capacity for moral sense. Our moral sense enables us to discern whether or not a given command deserves fulfilment or not. This is the same as saying that it is through our moral sense that we view ourselves as subject to a command; it attributes moral responsibility to the agent owing to the agent's capacity to fulfil it.

Finally, in the absence of a moral personality, it is not possible to recognize a command or a principle or a maxim, let alone the possibility of its fulfilment or non-fulfilment. This is the same as saying that there arises no moral responsibility in the absence of an auctor, recognizable command or an appraisal as to whether or not a command is morally obligatory or morally permissible.

In view of these points, we may suggest then, that it is only because we have a moral personality such as ours that we can be made morally responsible. That indeed, our moral personality is so constituted the way it is that it holds us morally responsible for the fulfilment of or violation of the principles, maxims, or laws that we ourselves regard as morally permissible and morally obligatory.

Nueva Ecija University of Science and Technology-MGT, Philippines

\section{References}

Allison, Henry, Essays on Kant (Oxford: Oxford University Press, 2012).

Kant's Theory of Taste: A Reading of the Critique of Aesthetic Judgment (Cambridge: Cambridge University Press, 2001).

Herman, Barbara, The Practice of Moral Judgment (Cambridge, MA: Harvard University Press, 1999).

Holzhey, Helmut and Vilem Mudroch, Historical Dictionary of Kant and Kantianism (Landham, Maryland: The Scarecrow Press, Inc., 2005). 


\section{A REREADING OF KANT'S ETHICS}

Hutcheson, Francis, An Inquiry into the Original of our Ideas of Beauty and Virtue in Two Treatises (Indianapolis: Liberty Fund, 2004).

Kant, Immanuel, Critique of Practical Reason, in Practical Philosophy, trans. and ed. by Mary J. Gregor and Allen Wood (Cambridge: Cambridge University Press, 1996).

Critique of the Power of Judgment, ed. by Paul Guyer and trans. by Paul Guyer and Eric Matthews (Cambridge: Cambridge University Press, 2000.

Groundwork of the Metaphysics of Morals, in Practical Philosophy, trans. and ed. by Mary J. Gregor and Allen Wood (Cambridge: Cambridge University Press, 1996).

"Kant on the Metaphysics of Morals: Vigilantus' Lecture Notes,"

in Lectures on Ethics, ed. by Peter Heath and J. B. Schneewind and trans. by Peter Heath (Cambridge: Cambridge University Press, 1997).

Lectures on Metaphysics, trans. and ed. by Karl Ameriks and Steve Naragon (Cambridge: Cambridge University Press, 1997).

"Morality according to Prof. Kant: Lectures on Baumgarten's Practical Philosophy," in Lectures on Ethics, ed. by Peter Heath and J. B. Schneewind and trans. by Peter Heath (Cambridge: Cambridge University Press, 1997).

"Notes on Moral Philosophy," in Notes and Fragments, ed. by Paul Guyer and trans. by Curtis Bowman, Paul Guyer, and Frederick Rauscher (Cambridge: Cambridge University Press, 2005).

"On the common saying: That may be correct in theory, but it is no use in practice," in Practical Philosophy, trans. and ed. by Mary J. Gregor and Allen Wood (Cambridge: Cambridge University Press, 1996).

Religion within the Boundaries of Mere Reason, in Religion and Rational Theology, trans. and ed. by Allen Wood and George Di Giovanni (Cambridge: Cambridge University Press, 1996).

The Metaphysics of Morals in Practical Philosophy, trans. and ed. by Mary J. Gregor (Cambridge: Cambridge University Press, 1996).

"To Marcus Herz, late 1773," in Correspondence, trans. and ed. by Arnulf Zweig (Cambridge: Cambridge University Press, 1999).

"Universal Natural History and Theory of the Heavens or, Essay on the Constitution and the Mechanical Origin of the Whole Universe according to Newtonian Principles," trans. by Olaf Reinhardt, in Natural Science, ed. by Eric Watkins (Cambridge: Cambridge University Press, 2012).

Korsgaard, Christine M., Creating the Kingdom of Ends (Cambridge: Cambridge University Press, 1999).

(C) 2019 Dennis A. De Vera

https://www.kritike.org/journal/issue 25/de vera december2019.pdf

ISSN 1908-7330

(cc) BY-NC-ND 
The Constitution of Agency: Essays on Practical Reason and Moral Psychology (Oxford: Oxford University Press, 2008).

MacIntyre, Alasdair, Hume's Ethical Writings: Selections from David Hume (Notre Dame: University of Notre Dame Press, 1965).

Rawls, John, "Kantian Constructivism in Moral Theory," in John Rawls: Collected Papers, ed. by Samuel Freeman (Cambridge, MA: Harvard University Press, 1999). Lectures on the History of Moral Philosophy (Cambridge, MA: Harvard University Press, 2000). Political Liberalism (New York: Columbia University Press, 1993). "The Sense of Justice" in Collected Papers, ed. by Samuel Freeman (Cambridge, MA: Harvard University Press, 1999).

"Themes in Kant's Moral Philosophy," in John Rawls: Collected Papers, ed. by Samuel Freeman (Cambridge, MA: Harvard University Press, 1999).

Smith, Adam, The Theory of Moral Sentiments (Cambridge: Cambridge University Press, 2004).

Strawson, Peter, "Freedom and Resentment," in Free Will, ed. by Gary Watson (Oxford: Oxford University Press, 2003).

Wilson, Holly, Kant's Pragmatic Anthropology: Its Origin, Meaning and Critical Significance (Albany: State University of New York Press, 2006).

Wood, Allen, "Kant and the Problem of Human Nature," in Essays in Kant's Anthropology, ed. by Brian Jacobs and Patrick Kain (Cambridge: Cambridge University Press, 2003).

Kant's Ethical Thought (Cambridge: Cambridge University Press, 1999).

Zweig, Arnulf, "Reflections on Kant's Ethics" in The Blackwell Guide to Kant's Ethics, ed. by Thomas E. Hill, Jr. (United Kingdom: Blackwell Publishing Ltd, 2009). 